\title{
EfFect of Dripline Flushing on Subsurface DRIP IRRIGATION SYSTEMS
}

\author{
J. Puig-Bargués, F. R. Lamm, T. P. Trooien, G. A. Clark
}

\begin{abstract}
The velocity of dripline flushing in subsurface drip irrigation (SDI) systems affects system design, cost, management, performance, and longevity. A 30-day field study was conducted at Kansas State University to analyze the effect of four targeted flushing velocities $(0.23,0.30,0.46$, and $0.61 \mathrm{~m} / \mathrm{s})$ for a fixed 15 min duration of flushing and three flushing frequencies (no flushing or flushing every 15 or 30 days) on SDI emitter discharge and sediments within the dripline and removed in the flushing water. At the end of the field experiment $(371 \mathrm{~h})$, the amount of solids carried away by the flushing water and retained in every lateral were determined as well as laboratory determination of emitter discharge for every single emitter within each dripline. Greater dripline flushing velocities, which also resulted in greater flushing volumes, tended to result in greater amounts of solids in the flushing water, but the differences were not always statistically significant. Neither the frequency of flushing nor the interaction of flushing frequency and velocity significantly affected the amount of solids in the flushing water. There was a greater concentration of solids in the beginning one-third of the $90 \mathrm{~m}$ laterals, particularly for treatments with no flushing or with slower dripline flushing velocities. As flushing velocity and concurrently flushing volume increased, there was a tendency for greater solids removal and/or more equal distribution within the dripline. At the end of the field study, the average emitter discharge as measured in the laboratory for a total of 3970 emitters was $0.64 \mathrm{~L} / \mathrm{h}$. which was significantly less (approximately 2.5\%) than the discharge for new and unused emitters. Only six emitters were nearly or fully clogged, with discharges between $0 \%$ and $5 \%$ of new and unused emitters. Flushing velocity and flushing frequency did not have consistent significant effects on emitter discharge, and those numerical differences that did exist were small $(<3 \%)$. Emitter discharge was approximately 3\% less for the distal ends of the driplines (last 20\% of the dripline). Although not a specific factor in the study, the results of solids removals during flushing and solids retention within the different dripline sections suggest that duration of flushing may be a more cost-effective management option than increasing the dripline flushing velocity through SDI system design. Finally, although microirrigation system components have been improved over the years, the need for flushing to remove solids and reduce clogging potential has not been eliminated.
\end{abstract}

Keywords. Clogging, Flushing, Lateral, Microirrigation.

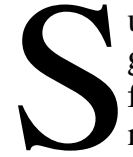
ubsurface drip irrigation (SDI) systems must have good and consistent filtration, water treatment, flushing, and maintenance plans to ensure long economic life (Lamm and Camp, 2007). Filtration systems do not normally remove clay and silt particles, algae, and bacteria. These particles may travel through the filters as individual particles, but then flocculate or become attached to organic residues and eventually become large enough to

Submitted for review in October 2009 as manuscript number SW 8254; approved for publication by the Soil \& Water Division of ASABE in January 2010. Presented at the 2009 ASABE Annual Meeting as Paper No. 096457.

Mention of tradenames is for informational purposes only and does not constitute endorsement by the authors or by the institutions they serve.

The authors are Jaume Puig-Bargués, Associate Professor, Department of Chemical and Agricultural Engineering and Technology, University of Girona, Girona Spain; Freddie R. Lamm, ASABE Member Engineer, Professor and Research Irrigation Engineer, Northwest Research Extension Center, Kansas State University, Colby, Kansas; Todd P. Trooien, ASABE Member Engineer, Professor, Department of Agricultural and Biosystems Engineering, South Dakota State University, Brookings, South Dakota; and Gary A. Clark, ASABE Member Engineer, Professor and Senior Associate Dean, College of Engineering, Kansas State University, Manhattan, Kansas. Corresponding author: Freddie R. Lamm, Northwest Research Extension Center, Kansas State University, 105 Experiment Farm Road, Colby, KS 67701; phone: 785-462-6281; fax: 785-462-2315; e-mail: flamm@ksu.edu. clog emitters (Nakayama et al., 2007). Therefore, dripline flushing is needed to remove these particles and organisms that have accumulated within the driplines (Adin and Sacks, 1991; Ravina et al., 1992).

Subsurface drip systems should be designed so they can be flushed properly. To be effective, flushing must be done often enough and at an appropriate velocity to dislodge and transport the accumulated sediments (Nakayama et al., 2007). A minimum flushing velocity of $0.3 \mathrm{~m} / \mathrm{s}$ is recommended for microirrigation systems (ASAE Standards, 2003). Lamm and Camp (2007) pointed out that the ASAE criterion seems appropriate for SDI in the absence of a stronger scientific reason for greater velocities. However, some researchers have suggested that a flushing velocity of 0.5 to $0.6 \mathrm{~m} / \mathrm{s}$ may be needed when larger particle sizes need to be discharged, such as when coarser filters are used (Hills and Brenes, 2001; Nakayama et al., 2007). Increasing the flushing velocity may require more costly system designs (e.g., pumping requirements, reduced zone sizes) and increase labor requirements for flushing (Lamm and Camp, 2007).

There is not a general agreement on the best flushing frequency. Several researchers have studied different flushing frequencies: daily (Ravina et al., 1997), twice per week (Tajrishy et al., 1994), once per week (Tajrishy et al., 1994; Hills et al., 2000), or every two weeks (Ravina et al., 1997; Hills and Brenes, 2001). However, for many systems, only one 
flushing is carried out at the beginning or at the end of the irrigation season.

The objectives of this research were to evaluate the effect of flushing velocity and flushing frequency on emitter clogging and to assess the distribution of sediments and emitter clogging in flushed and unflushed driplines.

\section{Procedures}

\section{EXPERIMENTAL SETUP}

The study was conducted during July and August 2004 on a deep, well-drained Keith silt loam soil (fine-silty, mixed, mesic Aridic Argiustoll) at the Kansas State University Northwest Research-Extension Center at Colby, Kansas.

The experimental setup consisted of 27 driplines installed at a depth of approximately $75 \mathrm{~mm}$ with an approximate length of $90 \mathrm{~m}$. The shallow installation depth was chosen for ease of dripline removal for subsequent testing at the end of the study, but it also helped protect the driplines from sunlight and other environmental conditions associated with surface drip irrigation (DI). The water source for the study was an unlined earthen reservoir to which groundwater could be periodically pumped for temporary storage prior to irrigation. The reservoir could also receive rainfall runoff water from adjacent fields, and this resulted in different reservoir silt loads. The water was filtered to a level of $75 \mu \mathrm{m}$ (200 mesh) with a three-canister disk filter prior to entering the driplines. The filtration system was automatically flushed every $2 \mathrm{~h}$ or at an inlet/outlet pressure differential of $49 \mathrm{kPa}$.

The dripline that was used was Netafim Typhoon 875, with an internal diameter (ID) of $22.2 \mathrm{~mm}$ and with emitters having a nominal discharge of $0.61 \mathrm{~L} / \mathrm{h}$ spaced every $0.61 \mathrm{~m}$. Three driplines (two black and one translucent) were installed at the same time with a tractor-mounted shank-type injector in the study area on an average field slope of $0.31 \%$.

Every dripline control head was equipped with an $\mathrm{ABB}$ C700 municipal-type volumetric flow accumulator $( \pm 1.5 \%$ accuracy), a Senninger low-flow pressure regulator (0.006 to $0.504 \mathrm{~L} / \mathrm{s}$ at $140 \mathrm{kPa}$ ), a $19 \mathrm{~mm}$ ID gate valve for flow adjustment, a $19 \mathrm{~mm}$ ball valve for quick shutoff, and a pressure gauge port. Another pressure gauge port was installed at the distal end of the dripline.

\section{TreatMents}

Nine treatments consisting of a control nonflushed treatment and a combination of flushing frequencies (15 or 30 days) and targeted flushing velocities $(0.23,0.30,0.46$, or $0.61 \mathrm{~m} / \mathrm{s}$ ) were examined in the study (table 1$)$. A research plot consisted of a single dripline, and each treatment was replicated three times in a randomized complete block for a total of 27 driplines. Each treatment had two plots with black driplines and a single plot with a translucent dripline. The translucent dripline was installed to allow for visual observation of the accumulated solids in the dripline at the end of the experiment. After installation with the shank-type injector, the driplines were uniformly cut to an installed length of $90.22 \mathrm{~m}$. However, due to uneven stretching and shrinking during installation, dripline lengths at the time of excavation varied from 89.50 to $90.29 \mathrm{~m}$ with the number of emitters varying from 146 to 148 (table 1 ).

The first irrigation event was initiated on July 13, and the sixteenth irrigation event was completed on August 13, 2004.
Table 1. Flushing frequency and flushing velocity treatments, plot number, dripline length, and number of emitters.

\begin{tabular}{|c|c|c|c|c|c|}
\hline $\begin{array}{c}\text { Treatment } \\
\text { No. }\end{array}$ & $\begin{array}{c}\text { No. of } \\
\text { Flushings }\end{array}$ & $\begin{array}{c}\text { Target } \\
\text { Flushing } \\
\text { Velocity } \\
(\mathrm{m} / \mathrm{s})\end{array}$ & $\begin{array}{l}\text { Plot } \\
\text { No. }\end{array}$ & $\begin{array}{l}\text { Dripline } \\
\text { Length } \\
\text { (m) }\end{array}$ & $\begin{array}{c}\text { No. of } \\
\text { Emitters }\end{array}$ \\
\hline \multirow{3}{*}{1} & \multirow{3}{*}{ None } & \multirow{3}{*}{-- } & 9 & 89.63 & 147 \\
\hline & & & 16 & 90.23 & 147 \\
\hline & & & 20 & 89.59 & 146 \\
\hline \multirow{3}{*}{2} & \multirow{12}{*}{$\begin{array}{c}\text { Single } \\
\text { flushing } \\
\text { occurring } \\
\text { at } 30 \text { days }\end{array}$} & \multirow{3}{*}{0.23} & 7 & 90.23 & 147 \\
\hline & & & 18 & 89.52 & 146 \\
\hline & & & 25 & 90.24 & 148 \\
\hline \multirow{3}{*}{3} & & \multirow{3}{*}{0.30} & 6 & 90.12 & 146 \\
\hline & & & 10 & 90.18 & 148 \\
\hline & & & 23 & 90.13 & 148 \\
\hline \multirow{3}{*}{4} & & \multirow{3}{*}{0.46} & 2 & 89.68 & 146 \\
\hline & & & 17 & 89.55 & 147 \\
\hline & & & 24 & 90.29 & 148 \\
\hline \multirow{3}{*}{5} & & \multirow{3}{*}{0.61} & 1 & 89.23 & 147 \\
\hline & & & 11 & 89.88 & 147 \\
\hline & & & 27 & 89.97 & 148 \\
\hline \multirow{3}{*}{6} & \multirow{12}{*}{$\begin{array}{l}\text { Two total } \\
\text { flushings } \\
\text { occurring } \\
\text { at } 15 \text { and } \\
30 \text { days }\end{array}$} & \multirow{3}{*}{0.23} & 8 & 89.89 & 147 \\
\hline & & & 15 & 89.71 & 146 \\
\hline & & & 19 & 90.34 & 148 \\
\hline \multirow{3}{*}{7} & & \multirow{3}{*}{0.30} & 3 & 89.50 & 146 \\
\hline & & & 14 & 89.93 & 147 \\
\hline & & & 22 & 89.92 & 147 \\
\hline \multirow{3}{*}{8} & & \multirow{3}{*}{0.46} & 4 & 90.28 & 147 \\
\hline & & & 12 & 89.61 & 147 \\
\hline & & & 26 & 89.62 & 148 \\
\hline \multirow{3}{*}{9} & & \multirow{3}{*}{0.61} & 5 & 90.07 & 147 \\
\hline & & & 13 & 90.02 & 147 \\
\hline & & & 21 & 89.64 & 147 \\
\hline
\end{tabular}

No crop was planted to the study area, and the area was grossly overirrigated during the summer to allow for more potential clogging and to allow for greater accumulation of solids within the driplines. The irrigation events were extended for long periods of time, but discrete events were used so that some rest periods could allow time for settling of solids (table 2). The flow rates for entire plots were measured approximately daily whenever the system was in operation. Pressure was measured at the dripline inlets and outlets at least once per irrigation event by means of a PSI-tronix pressure transducer $( \pm 0.07 \mathrm{kPa}$ accuracy). The average head loss during normal irrigation in the driplines was $0.21 \mathrm{kPa}$, once the dripline inlet and outlet height differences were considered. Every dripline flow rate was checked periodically during the irrigation season and adjusted as needed with the gate valve to the nominal level of $90.95 \mathrm{~L} / \mathrm{h}$.

Irrigation water at the plot inlet was sampled periodically during selected irrigation events to determine the total suspended solids (TSS) and water temperature. TSS were determined in the laboratory by filtering a sample through a previously weighed $2 \mu \mathrm{m}$ Whatman filter paper and drying the residue retained on the paper and the paper to a constant weight at $103^{\circ} \mathrm{C}$ to $105^{\circ} \mathrm{C}$. Temperature was measured with a liquid thermometer $\left( \pm 0.1^{\circ} \mathrm{C}\right.$ precision $)$. The average value of TSS for the periodic sampling was $19.2 \mathrm{mg} / \mathrm{L}$, with a minimum of $3.9 \mathrm{mg} / \mathrm{L}$ for the first irrigation event and a maximum 
Table 2. Characteristics of the sixteen irrigation events.

\begin{tabular}{ccccc}
\hline $\begin{array}{c}\text { Irrigation } \\
\text { Event }\end{array}$ & Dates & $\begin{array}{c}\text { Event } \\
\text { Time } \\
\text { (h) }\end{array}$ & $\begin{array}{c}\text { Cumulative } \\
\text { Time } \\
\text { (h) }\end{array}$ & $\begin{array}{c}\text { Approximate } \\
\text { Cumulative } \\
\text { Volume }^{[\mathrm{a}]} \\
\left(\mathrm{m}^{3}\right)\end{array}$ \\
\hline 1 & July 13 & 4.00 & 4.00 & 0.49 \\
2 & July 14 to 15 & 24.50 & 28.50 & 2.76 \\
3 & July 15 to 16 & 14.25 & 42.75 & 5.59 \\
4 & July 18 to 19 & 24.25 & 67.00 & 7.92 \\
5 & July 20 to 21 & 23.25 & 90.25 & 10.13 \\
6 & July 21 to 22 & 14.75 & 105.00 & 11.39 \\
7 & July 22 to 24 & 45.40 & 150.40 & 16.22 \\
8 & July 25 to 26 & 13.15 & 163.55 & 17.46 \\
9 & July 26 to 27 & 20.75 & 184.30 & 18.11 \\
10 & July 28 to 31 & 72.75 & 257.05 & 24.54 \\
11 & August 3 to 5 & 35.10 & 292.15 & 29.28 \\
12 & August 6 to 8 & 49.00 & 341.15 & 33.00 \\
13 & August 9 to 10 & 18.60 & 359.75 & 34.81 \\
14 & August 11 & 2.00 & 361.75 & 35.10 \\
15 & August 12 & 8.00 & 369.75 & 36.22 \\
16 & August 13 & 2.00 & 371.75 & 36.22 \\
\hline
\end{tabular}

[a] The irrigation volumes at the end of each event are approximate since the events were based on actual times and estimated dripline flow rates. Short-term adjustment events were conducted periodically over the course of the experiment to equalize total accumulated irrigation volumes. Event time adjustments to allow for identical accumulated flow amounts were conducted on July 27 and August 13.

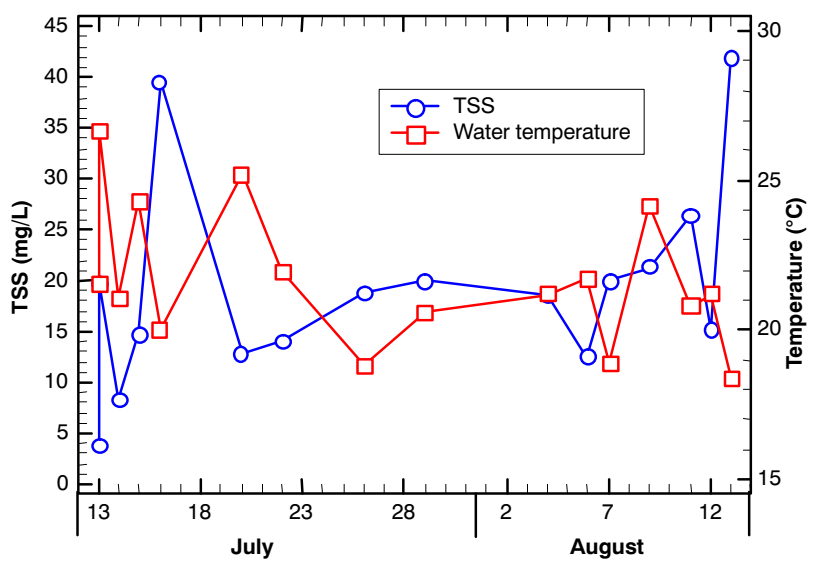

Figure 1. Time series of irrigation water total suspended solids (TSS) and temperature. of $41.9 \mathrm{mg} / \mathrm{L}$ for the last irrigation event (fig. 1). The cumulative amount of TSS applied through each dripline was estimated from linear interpolation of the TSS values on selected dates and multiplying those values by the total amount of applied water and was calculated to be approximately $6.9 \mathrm{~kg}$ for each dripline. The mean of the water temperature was $21.7^{\circ} \mathrm{C}$, with a maximum of $26.7^{\circ} \mathrm{C}$ on July 14 and a minimum of $18.4^{\circ} \mathrm{C}$ on August 13. The differences in water temperature are not only related to climatic conditions but also related to the residence time of the pumped groundwater in the surface reservoir. The pumped groundwater enters the reservoir at approximately $15^{\circ} \mathrm{C}$.

\section{Flushing Procedure}

The first flushing event was conducted when an amount of $18.1 \mathrm{~m}^{3}$ had been applied through each dripline on July 27 and 28. The second flushing event was performed on August 16 and 17 after a total of $36.2 \mathrm{~m}^{3}$ of water had been applied through each dripline. During the flushing events, the gate valve at the control head was carefully adjusted to allow the required treatment flushing velocity. The adjustment was made by raising the flow rate slowly over the course of approximately 3 to $5 \mathrm{~min}$ to avoid exceeding the required treatment flow velocity. However, even with this technique, actual flushing velocities slightly exceeded the targeted velocities (table 3 ). The flushing velocity also affected the flushing volume because the duration of the entire flushing event including the adjustment time was held constant at $15 \mathrm{~min}$. The average friction head loss during flushing as measured by the pressure transducer was approximately 9, 13,23 , and $39 \mathrm{kPa}$ with the target flushing velocities of 0.23 , $0.30,0.46$, and $0.61 \mathrm{~m} / \mathrm{s}$, respectively.

A removable $1 \mathrm{~m}$ standpipe and flush valve apparatus was added to the distal end of the dripline before the flushing event to simulate a possible elevation head that might be associated with flushing a subsurface dripline. All of the flushed water from a single dripline flushing event was collected in a $230 \mathrm{~L}$ tank. The total flushing water volume was filtered through a Culligan household water filter with a filtration level of $5 \mu \mathrm{m}$ in order to retain most of the suspended solids. The volume of flushing water collected in the tank was estimated by subtracting the estimated emitter discharge amount during flushing (approximately $6 \%$ to $11 \%$ of

Table 3. Flushing and flow rate characteristics (means \pm standard deviations) during the various dripline flushing events.

\begin{tabular}{|c|c|c|c|c|c|c|}
\hline \multirow{2}{*}{$\begin{array}{c}\text { No. of } \\
\text { Total } \\
\text { Flushings }\end{array}$} & \multirow{2}{*}{$\begin{array}{c}\text { Flushing } \\
\text { Event }\end{array}$} & \multicolumn{2}{|c|}{$\begin{array}{c}\text { Flushing Velocity } \\
(\mathrm{m} / \mathrm{s})\end{array}$} & \multirow{2}{*}{$\begin{array}{l}\text { Applied Flushing } \\
\text { Water Volume } \\
\text { (L) }\end{array}$} & \multirow{2}{*}{$\begin{array}{l}\text { Estimated Volume } \\
\text { of Flushing Water } \\
\text { Collected in Tank (L) }\end{array}$} & \multirow{2}{*}{$\begin{array}{c}\text { Dripline Flow Rate } \\
\text { during Event } \\
\left(\mathrm{m}^{3} / \mathrm{h}\right)\end{array}$} \\
\hline & & Target & Actual & & & \\
\hline \multirow{4}{*}{1} & \multirow{4}{*}{$\begin{array}{c}\text { August } \\
16 \text { to } 17\end{array}$} & 0.23 & 0.28 & $97 \pm 5$ & $88 \pm 5$ & $0.39 \pm 0.02$ \\
\hline & & 0.30 & 0.36 & $124 \pm 2$ & $113 \pm 2$ & $0.50 \pm 0.01$ \\
\hline & & 0.46 & 0.53 & $184 \pm 4$ & $171 \pm 4$ & $0.73 \pm 0.01$ \\
\hline & & 0.61 & 0.68 & $247 \pm 4$ & $231 \pm 5$ & $0.96 \pm 0.06$ \\
\hline \multirow{8}{*}{2} & \multirow{4}{*}{$\begin{array}{c}\text { July } \\
27 \text { to } 28\end{array}$} & 0.23 & 0.28 & $98 \pm 6$ & $88 \pm 6$ & $0.39 \pm 0.02$ \\
\hline & & 0.30 & 0.35 & $124 \pm 5$ & $113 \pm 5$ & $0.49 \pm 0.02$ \\
\hline & & 0.46 & 0.51 & $179 \pm 5$ & $166 \pm 5$ & $0.71 \pm 0.02$ \\
\hline & & 0.61 & 0.68 & $239 \pm 5$ & $224 \pm 4$ & $0.95 \pm 0.02$ \\
\hline & \multirow{4}{*}{$\begin{array}{c}\text { August } \\
16 \text { to } 17\end{array}$} & 0.23 & 0.27 & $96 \pm 5$ & $86 \pm 5$ & $0.38 \pm 0.02$ \\
\hline & & 0.30 & 0.35 & $122 \pm 7$ & $112 \pm 7$ & $0.49 \pm 0.03$ \\
\hline & & 0.46 & 0.51 & $179 \pm 0$ & $167 \pm 0$ & $0.72 \pm 0.00$ \\
\hline & & 0.61 & 0.69 & $240 \pm 3$ & $225 \pm 3$ & $0.96 \pm 0.01$ \\
\hline
\end{tabular}


total applied flushing water) from the applied flushing water volume (table 3 ). Although this volumetric calculation has some error, this estimate was thought to be much more accurate than using volumetric markings on the collection tank.

\section{Determination of the Amount of Solids in EACH DRIPLINE}

After the second flushing event, ten control lengths of each dripline were established. The lenqgths were measured from the distal end to the inlet of each lateral (i.e., section 1 at the inlet and section 10 at the distal end of dripline). Thus, there were nine sections (sections 2 through 10) of approximately $9.14 \mathrm{~m}$ and one section (section 1) of $7.92 \mathrm{~m}$. The longer sections (2 through 10) generally had 15 emitters for testing, while the shorter section 1 had approximately 13 emitters. Each section (control length) was established by exposing the dripline at the appropriate location and pinching it off with binder clamps. The sections were then carefully excavated and hauled on a $9.5 \mathrm{~m}$ flat bed trailer to the laboratory for emitter discharge tests. Each section was manually cleaned externally with a pressurized hose to remove excess soil and debris. After external cleaning, each section was placed on a sloping $(10 \%)$ platform where the clamps were removed and the trapped dirty water was allowed to drain into a $3 \mathrm{~L}$ rectangular container. A short ( $1 \mathrm{~s})$ burst of pressurized (approximately $140 \mathrm{kPa}$ ) water (approximately $2 \mathrm{~L}$ ) was then pumped through to dislodge additional loose sediments within the dripline. This water was also collected in the same container. The container was dried until a constant weight was reached, and then the amount of remaining solids was determined. This technique was used to provide an estimate of the amount of solids in each dripline, but it would not be able to account for any solids that failed to dislodge during the process.

\section{EmitTer Discharge Tests}

After the driplines were excavated, the discharge for each emitter in all ten dripline sections of each plot was measured in the laboratory. The laboratory setup allowed testing of six sections at the same time. Each of the six dripline sections was attached to a common inlet and outlet manifold system in which the driplines were suspended on a support rack made of $25 \mathrm{~mm}$ ID PVC pipe. The emitters from each drip lateral were aligned so that a collection cup rack could be used to simultaneously collect emitter discharges for the six driplines. Small cotton strings (kite string) attached to the dripline at each emitter extended approximately $70 \mathrm{~mm}$ below the dripline, were saturated during the conditioning periods, and then wicked water into the collection cups during an 18 min period. The fresh water used in these tests was pumped and recirculated from a $320 \mathrm{~L}$ tank that was filtered with an API $38 \mathrm{~mm}$ spin clean Y-filter with a $75 \mu \mathrm{m}$ (200 mesh) screen. Periodically, fresh water was added to the tank to replace water lost in the testing process and to maintain water temperature in an acceptable range $\left(23^{\circ} \mathrm{C}\right.$ to $\left.31^{\circ} \mathrm{C}\right)$. The water temperature was recorded to correct the water volume from the weight measurements. To account for the variation due to minor fluctuations in pressures from test to test, the calculated emitter discharges were normalized to the design pressure using the emitter exponent for that dripline type. The emitter discharge collection facility and the procedures used to evaluate emitter discharge in this study were adapted from facilities and procedures described by Clark et al. (2005).

\section{EMitTer Discharge Function}

Laboratory tests were performed on both new black and translucent driplines to determine the emitter discharge function coefficient and exponent. The procedure was similar to the procedures for testing the emitter discharge from the SDI driplines. The emitter discharge was measured under six different pressures $(43.3,53.0,64.4,65.6,83.7$, and $100.7 \mathrm{kPa})$. Discharge was measured for 30 emitters from each of the black (2) and translucent (1) rolls used in the field SDI installation.

The emitter discharge function obtained from the experimental data was:

$$
\begin{gathered}
q=0.0885 \cdot P^{0.4737} \\
\mathrm{R}^{2}=0.96, N=540, V_{m}=2.56 \%
\end{gathered}
$$

where $q$ is emitter discharge $(\mathrm{L} / \mathrm{h}), P$ is pressure $(\mathrm{kPa}), N$ is the number of emitters, and $V_{m}$ is the manufacturing coefficient of variation, calculated as:

$$
V_{m}=\frac{S_{q e}}{\bar{q}} \cdot 100
$$

where $S_{q e}$ is the standard deviation of emitter discharge, and $\bar{q}$ is the average emitter discharge. Evaluating the emitter discharge function at a nominal design pressure of $68.9 \mathrm{kPa}$ indicated that the emitter discharge is $7.7 \%(q=0.66$ instead of $0.61 \mathrm{~L} / \mathrm{h}$ ) greater than the manufacturer's specification. The emitter exponent determined in this procedure was used to normalize the measured emitter discharges from the used field study driplines to a standardized pressure. Additionally, the emitter discharge function was used to determine the emitter discharge of new and unused driplines at the nominal pressure of $68.9 \mathrm{kPa}$.

\section{Statistical Treatment}

Statistical analyses were conducted using the Proc GLM (general linear models) procedure of SAS (SAS Institute, Inc., Cary, N.C.) at a significance level of $p=0.05$. Total solids in the flushing water were analyzed with respect to both flushing velocity and frequency. When analyzing the dripline solids amount and emitter discharge for the various dripline sections, the model included as fixed effects the treatment (frequency of flushing and velocity), the section, and the interaction between them, when the interaction was significant. Tukey's test was used at the $\mathrm{p}=0.05$ level to separate the means.

\section{RESUlts AND Discussion \\ Solids In The Flushing Water}

The amount of total solids in the flushing water as measured by deposition on the filter cartridges (table 4) was significantly greater in the driplines flushed only once (August 16-17) with a targeted flushing velocity of $0.61 \mathrm{~m} / \mathrm{s}$ (actual velocity of $0.69 \mathrm{~m} / \mathrm{s}$ ) than for the smaller flushing velocities. This greater targeted flushing velocity also resulted in significantly greater solids removal for the first flushing (July 27-28) event for the 15-day flushing frequency, but solids removal was statistically similar for the second flushing event 
Table 4. Total solids (g) in the flushing water as measured in the water filter cartridges (mean values \pm standard deviations) as affected by the number of flushings and flushing velocity.

\begin{tabular}{|c|c|c|c|c|c|}
\hline \multirow{3}{*}{$\begin{array}{c}\text { No. of } \\
\text { Total } \\
\text { Flushings }\end{array}$} & \multirow{3}{*}{$\begin{array}{c}\text { Flushing } \\
\text { Event }\end{array}$} & \multicolumn{4}{|c|}{ Target Flushing Velocity $\left(\mathrm{m} / \mathrm{s}\right.$, with range of actual velocities in parentheses) ${ }^{[\mathrm{a}]}$} \\
\hline & & 0.23 & 0.30 & 0.46 & 0.61 \\
\hline & & $(0.27-0.28)$ & $(0.35-0.36)$ & $(0.51-0.53)$ & $(0.68-0.69)$ \\
\hline \multirow{3}{*}{2} & July $27-28$ & $0.56 \pm 0.2 b$ & $0.9 \pm 0.9 \mathrm{~b}$ & $1.3 \pm 0.6 \mathrm{~b}$ & $4.0 \pm 1.7 \mathrm{a}$ \\
\hline & August $16-17$ & $14.5 \pm 2.8 \mathrm{a}$ & $15.2 \pm 3.7 \mathrm{a}$ & $17.2 \pm 0.7 \mathrm{a}$ & $17.1 \pm 1.9 \mathrm{a}$ \\
\hline & Total of both & $15.0 \pm 1.76 \mathrm{~B}$ & $16.1 \pm 2.6 \mathrm{~B}$ & $18.5 \pm 0.4 \mathrm{AB}$ & $21.1 \pm 1.8 \mathrm{AB}$ \\
\hline 1 & August 16-17 & $12.9 \pm 3.1 \mathrm{Bb}$ & $16.8 \pm 4.4 \mathrm{ABb}$ & $16.9 \pm 1.0 \mathrm{ABb}$ & $27.0 \pm 6.0 \mathrm{Aa}$ \\
\hline
\end{tabular}

[a] Different uppercase letters indicate significant differences $(\mathrm{p}<0.05)$ between values for each flushing frequency (rows).

Different lowercase letters indicate significant differences $(\mathrm{p}<0.05)$ between flushing velocities for each flushing event (columns).

(August 16-17). When comparing the flushing velocities across the flushing frequencies, the greater targeted $0.61 \mathrm{~m} / \mathrm{s}$ flushing velocity resulted in significantly greater flushed solids than the targeted $0.23 \mathrm{~m} / \mathrm{s}$ flushing velocity and those flushed twice with a targeted flushing velocity of $0.30 \mathrm{~m} / \mathrm{s}$. There was a tendency that the greater the flushing velocity (which also resulted in greater flushing volume), the greater the amount of solids in the flushing water. Only the flushing velocity factor had a significant effect on the results, with neither the flushing frequency nor the interaction of frequency and velocity significantly affecting the amount of total solids retained on the filter cartridges. However, the variability of the results with large standard deviations should be noted. There were no significant differences among flushing velocities for the August 16-17 flushing for the treatments that received two flushings, but for the July 27-28 flushing and for the single flushing treatment of August 16-17, there were sig- nificantly greater solids deposition on the cartridge for the $0.61 \mathrm{~m} / \mathrm{s}$ targeted flushing velocity.

\section{SOLIDS WITHIN THE DRIPLINES}

At the conclusion of the field study, the amount of solids in each of the ten dripline sections for each single dripline replication for each flushing treatment was determined through the drainage and short-burst pressurized water cleaning procedure discussed in the Procedures. There was a statistical interaction between dripline section and flushing treatment for the amount of solids within the dripline. Thus, the effects of section and treatment cannot be considered independently.

As might be expected, the maximum amount of solids for both the overall dripline and each individual section occurred in the driplines that were not flushed during the study (table 5 and fig. 2). For most of the dripline sections, no differences

Table 5. Average \pm standard deviation of solids (g) loosely retained in the driplines after the flushing events as related to dripline section and flushing treatment. Section 1 is at the inlet, and section 10 is at the distal end.

\begin{tabular}{|c|c|c|c|c|c|c|c|c|c|}
\hline \multirow[b]{3}{*}{ Section } & \multicolumn{9}{|c|}{ Target Flushing Velocity (m/s, with range of actual velocities in parentheses) ${ }^{[\mathrm{a}]}$} \\
\hline & & \multicolumn{4}{|c|}{1 Flushing } & \multicolumn{4}{|c|}{2 Flushings } \\
\hline & 0 & $\begin{array}{c}0.23 \\
(0.27-0.28)\end{array}$ & $\begin{array}{c}0.30 \\
(0.35-0.36)\end{array}$ & $\begin{array}{c}0.46 \\
(0.51-0.53)\end{array}$ & $\begin{array}{c}0.61 \\
(0.68-0.69)\end{array}$ & $\begin{array}{c}0.23 \\
(0.27-0.28)\end{array}$ & $\begin{array}{c}0.30 \\
(0.35-0.36)\end{array}$ & $\begin{array}{c}0.46 \\
(0.51-0.53)\end{array}$ & $\begin{array}{c}0.61 \\
(0.68-0.69)\end{array}$ \\
\hline 1 & $\begin{array}{c}4.47 \\
\pm 0.14 \mathrm{aA}\end{array}$ & $\begin{array}{c}1.51 \\
\pm 0.94 \mathrm{~b}\end{array}$ & $\begin{array}{c}1.27 \\
\pm 0.23 \mathrm{bAB}\end{array}$ & $\begin{array}{c}1.11 \\
\pm 0.60 \mathrm{~b}\end{array}$ & $\begin{array}{c}1.08 \\
\pm 0.70 \mathrm{~b}\end{array}$ & $\begin{array}{c}1.26 \\
\pm 0.39 \mathrm{~b} \\
\end{array}$ & $\begin{array}{c}1.53 \\
\pm 0.74 \mathrm{~b}\end{array}$ & $\begin{array}{c}1.15 \\
\pm 0.76 \mathrm{~b}\end{array}$ & $\begin{array}{c}0.93 \\
\pm 0.37 \mathrm{~b}\end{array}$ \\
\hline 2 & $\begin{array}{c}4.79 \\
\pm 0.69 \mathrm{aA} \\
\end{array}$ & $\begin{array}{c}1.83 \\
\pm 0.93 \mathrm{~b} \\
\end{array}$ & $\begin{array}{c}1.62 \\
\pm 0.37 \mathrm{bAB}\end{array}$ & $\begin{array}{c}1.39 \\
\pm 0.45 \mathrm{~b}\end{array}$ & $\begin{array}{c}0.78 \\
\pm 0.54 \mathrm{~b}\end{array}$ & $\begin{array}{c}1.71 \\
\pm 0.48 \mathrm{~b}\end{array}$ & $\begin{array}{c}1.50 \\
\pm 0.15 \mathrm{~b} \\
\end{array}$ & $\begin{array}{c}1.25 \\
\pm 0.49 \mathrm{~b}\end{array}$ & $\begin{array}{c}1.17 \\
\pm 0.29 \mathrm{~b}\end{array}$ \\
\hline 3 & $\begin{array}{c}4.93 \\
\pm 0.08 \mathrm{aA} \\
\end{array}$ & $\begin{array}{c}1.86 \\
\pm 0.20 \mathrm{~b} \\
\end{array}$ & $\begin{array}{c}1.89 \\
\pm 0.26 \mathrm{bA} \\
\end{array}$ & $\begin{array}{c}1.15 \\
\pm 0.06 \mathrm{~cd} \\
\end{array}$ & $\begin{array}{c}0.91 \\
\pm 0.21 \mathrm{~d} \\
\end{array}$ & $\begin{array}{c}1.65 \\
\pm 0.40 \mathrm{bc}\end{array}$ & $\begin{array}{c}1.59 \\
\pm 0.18 \text { bcd }\end{array}$ & $\begin{array}{c}1.28 \\
\pm 0.33 \text { bcd }\end{array}$ & $\begin{array}{c}1.33 \\
\pm 0.30 \mathrm{bcd}\end{array}$ \\
\hline 4 & $\begin{array}{c}3.88 \\
\pm 0.55 \mathrm{aAB} \\
\end{array}$ & $\begin{array}{c}1.63 \\
\pm 0.20 \mathrm{~b} \\
\end{array}$ & $\begin{array}{c}1.46 \\
\pm 0.13 \mathrm{bAB}\end{array}$ & $\begin{array}{c}1.18 \\
\pm 0.22 \mathrm{~b} \\
\end{array}$ & $\begin{array}{c}0.76 \\
\pm 0.47 \mathrm{~b} \\
\end{array}$ & $\begin{array}{c}1.47 \\
\pm 0.09 \mathrm{~b} \\
\end{array}$ & $\begin{array}{c}1.24 \\
\pm 0.26 \mathrm{~b} \\
\end{array}$ & $\begin{array}{c}1.06 \\
\pm 0.27 \mathrm{~b} \\
\end{array}$ & $\begin{array}{c}1.18 \\
\pm 0.53 \mathrm{~b} \\
\end{array}$ \\
\hline 5 & $\begin{array}{c}3.29 \\
\pm 0.61 \mathrm{aBC} \\
\end{array}$ & $\begin{array}{c}1.63 \\
\pm 0.22 \mathrm{~b} \\
\end{array}$ & $\begin{array}{c}1.55 \\
\pm 0.30 \mathrm{bAB} \\
\end{array}$ & $\begin{array}{c}1.00 \\
\pm 0.18 \mathrm{~b} \\
\end{array}$ & $\begin{array}{c}0.92 \\
\pm 0.43 \mathrm{~b} \\
\end{array}$ & $\begin{array}{c}0.95 \\
\pm 0.04 \mathrm{~b} \\
\end{array}$ & $\begin{array}{c}1.23 \\
\pm 0.23 \mathrm{~b} \\
\end{array}$ & $\begin{array}{c}1.28 \\
\pm 0.36 \mathrm{~b} \\
\end{array}$ & $\begin{array}{c}1.04 \\
\pm 0.16 \mathrm{~b} \\
\end{array}$ \\
\hline 6 & $\begin{array}{c}3.10 \\
\pm 0.17 \text { aBCD } \\
\end{array}$ & $\begin{array}{c}1.27 \\
\pm 0.25 \mathrm{~b} \\
\end{array}$ & $\begin{array}{c}1.25 \\
\pm 0.39 \mathrm{bAB} \\
\end{array}$ & $\begin{array}{c}1.10 \\
\pm 0.19 \mathrm{~b} \\
\end{array}$ & $\begin{array}{c}0.80 \\
\pm 0.38 \mathrm{~b} \\
\end{array}$ & $\begin{array}{c}1.09 \\
\pm 0.36 \mathrm{~b} \\
\end{array}$ & $\begin{array}{c}1.27 \\
\pm 0.27 \mathrm{~b} \\
\end{array}$ & $\begin{array}{c}1.12 \\
\pm 0.42 \mathrm{~b} \\
\end{array}$ & $\begin{array}{c}1.29 \\
\pm 0.15 \mathrm{~b} \\
\end{array}$ \\
\hline 7 & $\begin{array}{c}3.02 \\
\pm 0.11 \mathrm{aBCD}\end{array}$ & $\begin{array}{c}1.14 \\
\pm 0.19 \mathrm{~b}\end{array}$ & $\begin{array}{c}1.30 \\
\pm 0.10 \mathrm{bAB}\end{array}$ & $\begin{array}{c}1.04 \\
\pm 0.18 \mathrm{~b} \\
\end{array}$ & $\begin{array}{c}0.97 \\
\pm 0.30 \mathrm{~b}\end{array}$ & $\begin{array}{c}1.23 \\
\pm 0.28 \mathrm{~b} \\
\end{array}$ & $\begin{array}{c}1.13 \\
\pm 0.27 \mathrm{~b} \\
\end{array}$ & $\begin{array}{c}1.12 \\
\pm 0.50 \mathrm{~b} \\
\end{array}$ & $\begin{array}{c}1.73 \\
\pm 0.59 \mathrm{~b} \\
\end{array}$ \\
\hline 8 & $\begin{array}{c}2.43 \\
\pm 0.56 \mathrm{aCD} \\
\end{array}$ & $\begin{array}{c}0.98 \\
\pm 0.19 \mathrm{~b} \\
\end{array}$ & $\begin{array}{c}1.03 \\
\pm 0.25 \mathrm{bB} \\
\end{array}$ & $\begin{array}{c}0.90 \\
\pm 0.18 \mathrm{~b} \\
\end{array}$ & $\begin{array}{c}0.89 \\
\pm 0.20 \mathrm{~b} \\
\end{array}$ & $\begin{array}{c}0.99 \\
\pm 0.15 \mathrm{~b} \\
\end{array}$ & $\begin{array}{c}0.98 \\
\pm 0.23 \mathrm{~b} \\
\end{array}$ & $\begin{array}{c}1.23 \\
\pm 0.45 \mathrm{~b}\end{array}$ & $\begin{array}{c}1.32 \\
\pm 0.18 \mathrm{~b}\end{array}$ \\
\hline 9 & $\begin{array}{c}2.07 \\
\pm 0.08 \mathrm{aD}\end{array}$ & $\begin{array}{c}1.12 \\
\pm 0.35 \mathrm{~b}\end{array}$ & $\begin{array}{c}1.02 \\
\pm 0.09 \mathrm{bB}\end{array}$ & $\begin{array}{c}0.94 \\
\pm 0.39 \mathrm{~b}\end{array}$ & $\begin{array}{c}0.80 \\
\pm 0.48 \mathrm{~b}\end{array}$ & $\begin{array}{c}0.95 \\
\pm 0.12 \mathrm{~b}\end{array}$ & $\begin{array}{c}0.85 \\
\pm 0.05 \mathrm{~b}\end{array}$ & $\begin{array}{c}1.17 \\
\pm 0.19 \mathrm{~b}\end{array}$ & $\begin{array}{c}1.30 \\
\pm 0.22 \mathrm{~b}\end{array}$ \\
\hline 10 & $\begin{array}{c}2.38 \\
\pm 0.07 \mathrm{aCD}\end{array}$ & $\begin{array}{c}1.05 \\
\pm 0.12 \mathrm{~b} \\
\end{array}$ & $\begin{array}{c}1.13 \\
\pm 0.10 \mathrm{bB}\end{array}$ & $\begin{array}{c}1.12 \\
\pm 0.14 \mathrm{~b} \\
\end{array}$ & $\begin{array}{c}1.01 \\
\pm 0.29 \mathrm{~b}\end{array}$ & $\begin{array}{c}1.15 \\
\pm 0.37 \mathrm{~b} \\
\end{array}$ & $\begin{array}{c}1.53 \\
\pm 0.27 \mathrm{~b} \\
\end{array}$ & $\begin{array}{c}1.26 \\
\pm 0.57 \mathrm{~b} \\
\end{array}$ & $\begin{array}{c}1.54 \\
\pm 0.18 \mathrm{~b} \\
\end{array}$ \\
\hline $\begin{array}{l}\text { Overall } \\
\text { dripline }\end{array}$ & $\begin{array}{c}34.4 \\
\pm 1.86 \mathrm{a}\end{array}$ & $\begin{array}{c}14.1 \\
\pm 2.74 \mathrm{~b}\end{array}$ & $\begin{array}{c}13.6 \\
\pm 0.19 \mathrm{~b}\end{array}$ & $\begin{array}{c}11.0 \\
\pm 1.90 \mathrm{~b}\end{array}$ & $\begin{array}{c}8.95 \\
\pm 3.86 \mathrm{~b}\end{array}$ & $\begin{array}{c}12.5 \\
\pm 2.10 \mathrm{~b}\end{array}$ & $\begin{array}{c}12.9 \\
\pm 2.03 \mathrm{~b}\end{array}$ & $\begin{array}{c}12.0 \\
\pm 3.97 \mathrm{~b}\end{array}$ & $\begin{array}{c}12.9 \\
\pm 1.29 \mathrm{~b}\end{array}$ \\
\hline
\end{tabular}

[a] Within each section and overall dripline, different lowercase letters indicate significant differences $(\mathrm{P}<0.05)$ among flushing treatments (the columns of the table). Within each flushing treatment, different uppercase letters indicate significant differences $(\mathrm{P}<0.05)$ among dripline sections (the rows of the table). 


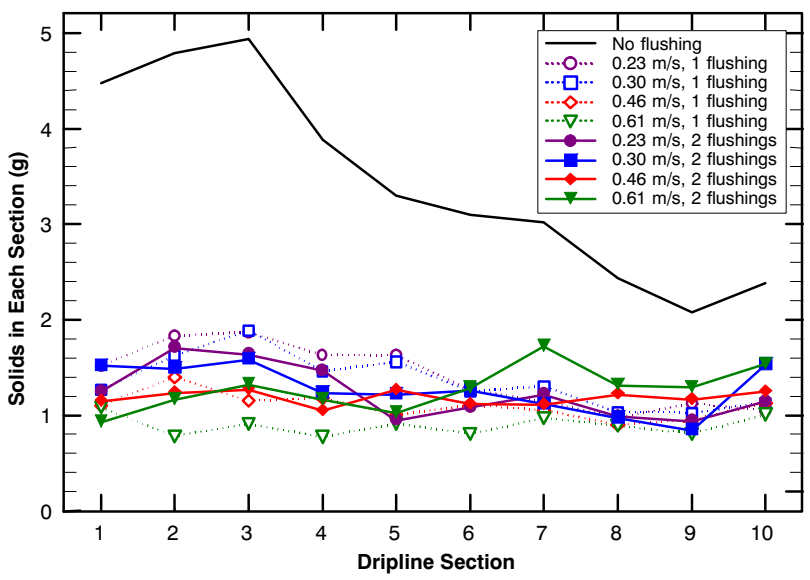

Figure 2. Solids recovered from each dripline section and flushing treatment at the end of the field study. Section 1 is at the inlet, and section 10 is at the distal end. Actual flushing velocities were slightly greater than shown in the legend (see table 3 for range of flushing velocities).

were observed in the amount of solids contents with regard to flushing velocity and flushing frequency. Only in section 3 (17.1 to $29.3 \mathrm{~m}$ from dripline inlet) was the amount of dripline solids significantly greater for the smaller flushing velocities and frequencies (i.e., target velocities of $0.23 \mathrm{~m} / \mathrm{s}$ and $0.30 \mathrm{~m} / \mathrm{s}$ with one flushing and also $0.23 \mathrm{~m} / \mathrm{s}$ with two flushings when compared with $0.61 \mathrm{~m} / \mathrm{s}$ with one flushing). The amount of solids was also greatest in section 3 for the treatment that was not flushed. This section may have the greatest amount of solids because of greater deposition there during normal irrigation events as flow velocity decreased along the dripline to a threshold level. The flow velocity at the midpoint of section 3 can be estimated to be approximately $0.05 \mathrm{~m} / \mathrm{s}$ during normal irrigation events (assuming an approximate nominal emitter discharge along the dripline), which would be an approximately $25 \%$ velocity reduction from the inlet. These results concerning the location of solids deposition do not agree with those obtained by Shannon et al. (1982), who found that sediment deposition began at about $61 \mathrm{~m}$ in $122 \mathrm{~m}$ driplines, increased steadily until about $110 \mathrm{~m}$, and then decreased in the last $10 \mathrm{~m}$.

As flushing velocity and concurrently the flushing volume increased, there was a tendency for the greatest amount of solids removal and/or more equal distribution within the dripline (fig. 2). Flushing frequency had a less consistent effect on solids removal and distribution, with the single flushing event sometimes being better than the two flushing events (table 5). It is possible that, when sediments are allowed to accumulate and conglomerate over a longer time period, these aggregates might have some dragging effect on other sediments during flushing, and thus the solids removal might be greater. Additionally, greater deposition over a longer time period between flushing events would decrease the cross-sectional area of the dripline, which would then increase the localized flushing velocity at that point for a given overall dripline flow rate. Results obtained by Shannon et al. (1982) indicate that the sediments move similarly to sand dunes, with building up of deposits followed by erosion of the highest margins exposed to greater flow velocities, and then the process starts again farther along the dripline. These overall results suggest that longer flushing duration (and increased flushing volumes) would be required to further reduce the amount of sediments remaining in the driplines.

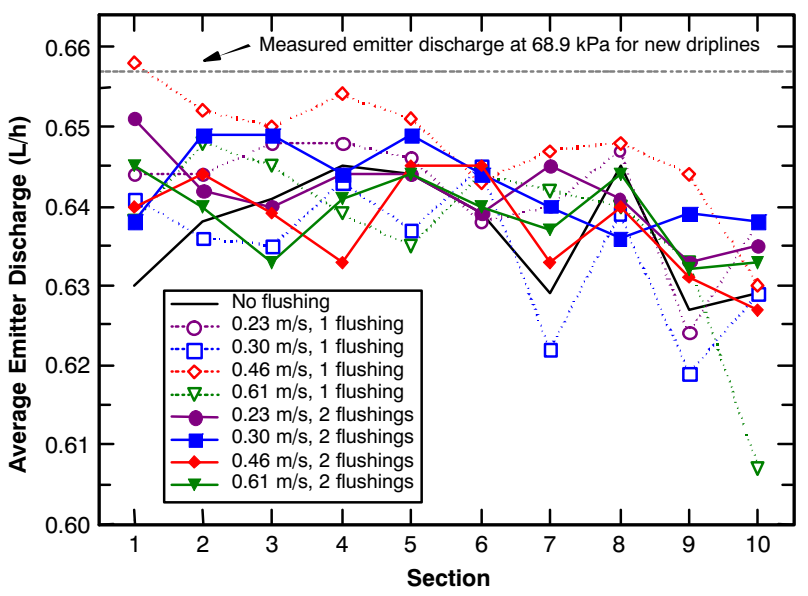

Figure 3. Average emitter discharge for each dripline section as affected by flushing velocity and number of flushings. Section 1 is at the inlet, and section 10 is at the distal end. Note: The average emitter discharge for the dripline sections only varies by less than $8 \%$. Actual flushing velocities were slightly greater than shown in the legend (see table 3 for range of flushing velocities).

\section{EMITTER DisChARGE}

The average emitter discharge at the conclusion of the field experiment was measured in the laboratory, and the discharge value was normalized to the nominal pressure $(68.9 \mathrm{kPa})$. Although data are available for each emitter, it is impractical to present emitter-by-emitter differences along the length of the dripline for all flushing treatments in a single graph because of the range of possible discharges (i.e., fully clogged to $100 \%$ discharge). Thus, a reasonable compromise was to depict trends in the average emitter discharge within a dripline section (fig. 3). Most of the emitter discharges were within $5 \%$ of the new, unused emitter average discharge of $0.66 \mathrm{~L} / \mathrm{h}$ at a pressure of $68.9 \mathrm{kPa}$, as measured in the laboratory (fig. 3 and table 6). The average emitter discharge for a total of 3970 emitters from the field study was $0.64 \mathrm{~L} / \mathrm{h}$, which was significantly less (approximately $2.5 \%$ ) than the discharge for the new, unused emitters (fig. 4). Only six emitters were nearly or fully clogged (i.e., $0 \%$ to $5 \%$ of discharge of new and unused emitters).

There was no statistically significant interaction between flushing treatment and dripline section, so it is legitimate to discuss these effects separately. Least square means and their associated standard errors were computed for the different flushing treatments and for the different dripline sections (figs. 4 and 5). Least square means are depicted here because of greater statistical accuracy in means separation when there are differences in sample size. However, in this case, there were only very minor differences in sample size, and each treatment sample size was approximately 440 emitters, so there is very little difference between the least square means and the simple mathematical means of the treatments (table 7).

There was a statistically significant difference $(\mathrm{p}<0.05)$ in emitter discharge from the SDI emitters, with the single flushing treatment with target flushing velocity of $0.46 \mathrm{~m} / \mathrm{s}$ being significantly greater than when flushing twice at targeted flushing velocities of 0.46 and $0.61 \mathrm{~m} / \mathrm{s}$, flushing once at 0.30 and $0.61 \mathrm{~m} / \mathrm{s}$, and without flushing (fig. 4 and table 7). However, the numerical differences between the treatments are quite small and may have little practical consequence. These numerical and statistical differences are not explained 
Table 6. Percentage of SDI emitters from the field study having a specified fraction of the discharge of new, unused emitters for the various flushing treatments.

\begin{tabular}{|c|c|c|c|c|c|c|c|c|c|}
\hline \multirow{3}{*}{$\begin{array}{l}\text { Fraction } \\
\text { of New } \\
\text { Emitter } \\
\text { Discharge }\end{array}$} & \multicolumn{9}{|c|}{ Target Flushing Velocity (m/s, with range of actual velocities in parentheses) } \\
\hline & \multirow[b]{2}{*}{0} & \multicolumn{4}{|c|}{1 Flushing } & \multicolumn{4}{|c|}{2 Flushings } \\
\hline & & $\begin{array}{c}0.23 \\
(0.27-0.28)\end{array}$ & $\begin{array}{c}0.30 \\
(0.35-0.36)\end{array}$ & $\begin{array}{c}0.46 \\
(0.51-0.53)\end{array}$ & $\begin{array}{c}0.61 \\
(0.68-0.69)\end{array}$ & $\begin{array}{c}0.23 \\
(0.27-0.28)\end{array}$ & $\begin{array}{c}0.30 \\
(0.35-0.36)\end{array}$ & $\begin{array}{c}0.46 \\
(0.51-0.53)\end{array}$ & $\begin{array}{c}0.61 \\
(0.68-0.69)\end{array}$ \\
\hline $1.1-1.2$ & 0.2 & -- & -- & -- & -- & -- & -- & -- & -- \\
\hline $1.0-1.1$ & 27.0 & 26.8 & 32.5 & 24.7 & 30.2 & 30.8 & 21.7 & 40.1 & 31.9 \\
\hline $0.9-1.0$ & 66.6 & 70.5 & 62.7 & 69.9 & 65.1 & 65.1 & 73.5 & 56.0 & 62.4 \\
\hline $0.8-0.9$ & 5.2 & 2.0 & 4.5 & 4.3 & 3.6 & 3.2 & 3.4 & 3.9 & 4.1 \\
\hline $0.7-0.8$ & 0.5 & 0.2 & 0.2 & 0.9 & 0.5 & 0.5 & 0.7 & -- & 0.2 \\
\hline $0.6-0.7$ & 0.2 & 0.2 & -- & -- & -- & 0.2 & -- & -- & 0.7 \\
\hline $0.5-0.6$ & -- & -- & -- & -- & -- & -- & -- & -- & 0.0 \\
\hline $0.4-0.5$ & -- & -- & -- & 0.2 & 0.5 & -- & -- & -- & 0.2 \\
\hline $0.3-0.4$ & -- & 0.2 & -- & -- & -- & -- & -- & -- & -- \\
\hline $0.2-0.3$ & -- & -- & -- & -- & -- & -- & -- & -- & -- \\
\hline $0.1-0.2$ & -- & -- & -- & -- & -- & -- & 0.2 & -- & -- \\
\hline $0.0-0.1$ & 0.2 & -- & -- & -- & 0.2 & -- & 0.5 & -- & 0.5 \\
\hline
\end{tabular}

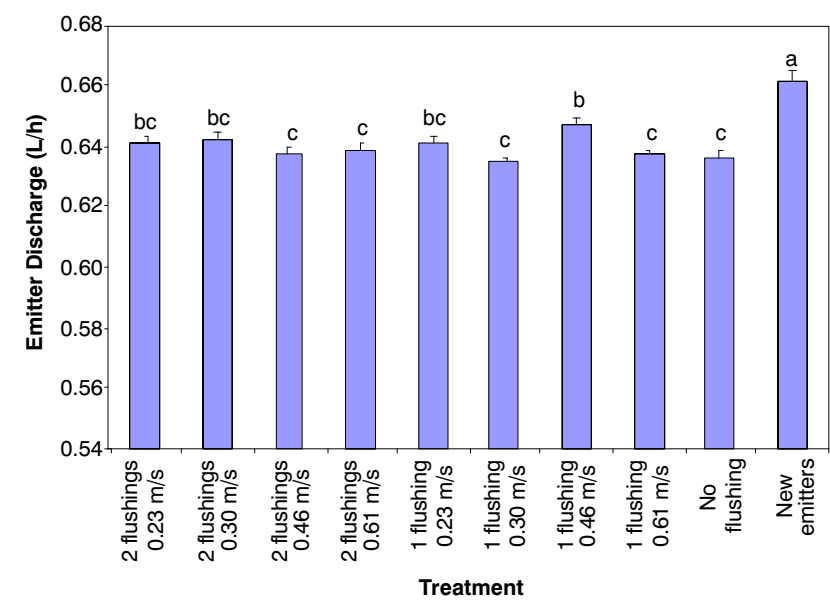

Figure 4. Discharge from the SDI emitters (least square mean \pm standard error) as affected by flushing frequency and flushing velocity. Different lowercase letters above each column indicate significant differences at $\mathbf{p}<$ 0.05 . The data are averaged across all dripline sections to represent the overall effect of flushing treatment on the dripline. Actual flushing velocities were slightly greater than shown in the $x$-axis labels (see table 3 for range of flushing velocities).

logically from the treatment structure, and they do not appear consistent with typical hypotheses that increased flushing frequency and increased flushing velocity will help prevent emitter clogging and thus retain greater emitter discharges. The results may be reflecting improvements in emitter design and manufacturing and improved filtration systems that may have reduced some of the clogging potential for SDI emitters (Camp et al., 2000). Additionally, the emitters used in this study were integral type, short flow-path, welded-on emitters, which some researchers have stated typically have better performance with sediment-laden water (Adin and Sacks, 1991; Hills and Brenes, 2001; Trooien and Hills, 2007). It should be restated that it is estimated that nearly $7 \mathrm{~kg}$ of TSS flowed through each dripline (approximately $90 \mathrm{~m}$ ) during the course of the field experiment, so this was an appreciable sediment load to contend with. Assuming a particle density of the solid material of $2.65 \mathrm{~g} / \mathrm{cm}^{3}$, this nearly $7 \mathrm{~kg}$ of TSS would represent approximately $7.5 \%$ of the total $90 \mathrm{~m}$ inter-

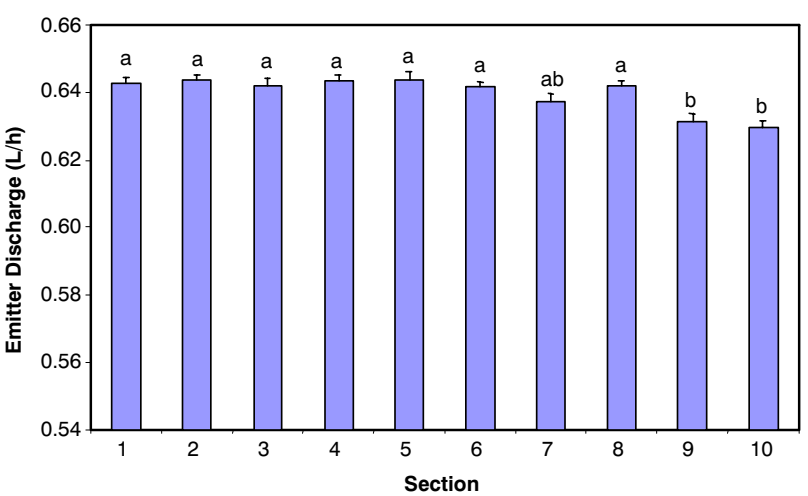

Figure 5. Discharge from the SDI emitters (least square mean \pm standard error) as affected by section of the dripline (section 1 is the inlet, and section 10 is the distal end). Different lowercase letters above each column indicate significant differences at $p<0.05$. The data are averaged across all flushing treatments to indicate the effect of location within the dripline on emitter clogging.

nal dripline volume. The TSS values ranged from about 4 to $42 \mathrm{mg} / \mathrm{L}$ during the course of the study, which is near the midrange of several studies using microirrigation for biological effluents (table 9.1 in Trooien and Hills, 2007). Emitter clogging can be caused by physical, biological, or chemical constituents or any combination of the three. Physical constituents, as a host site, combined with biological constituents providing the adhesive properties, can result in larger emitter clogging conglomerates. There were also some statistically significant differences in flushing treatment on solids deposition within the dripline. The small reductions in emitter discharge and the small amount of severely clogged emitters in this study does not mean that dripline flushing is not important.

The statistical analysis with regard to distance along the dripline (i.e., dripline section) indicates that the discharge of emitters in sections 1 to 6 (0 to $53.6 \mathrm{~m})$ and section 8 (62.8 to 71.9 $\mathrm{m}$ ) was significantly greater (fig. 5 and table 7) than the discharge of emitters in sections 9 and 10 (from 71.9 to $90.2 \mathrm{~m}$ ). These results agree with the results of other research (Shannon et al., 1982; Ravina et al., 1992), which indicated increased clogging and sediment deposition in the distal sections. 
Table 7. Emitter discharge $(\mathrm{L} / \mathrm{h})$ for the SDI emitters (average \pm standard deviation) as measured

in the laboratory at the end of the field experiment for every flushing treatment and dripline section.

\begin{tabular}{|c|c|c|c|c|c|c|c|c|c|c|}
\hline \multirow[b]{3}{*}{ Section } & \multicolumn{9}{|c|}{ Target Flushing Velocity (m/s, with range of actual velocities in parentheses) ${ }^{[a]}$} & \multirow{3}{*}{$\begin{array}{c}\text { All } \\
\text { Flushing } \\
\text { Treatments }\end{array}$} \\
\hline & \multirow[b]{2}{*}{0} & \multicolumn{4}{|c|}{1 Flushing } & \multicolumn{4}{|c|}{2 Flushings } & \\
\hline & & $\begin{array}{c}0.23 \\
(0.27-0.28)\end{array}$ & $\begin{array}{c}0.30 \\
(0.35-0.36)\end{array}$ & $\begin{array}{c}0.46 \\
(0.51-0.53)\end{array}$ & $\begin{array}{c}0.61 \\
(0.68-0.69)\end{array}$ & $\begin{array}{c}0.23 \\
(0.27-0.28)\end{array}$ & $\begin{array}{c}0.30 \\
(0.35-0.36)\end{array}$ & $\begin{array}{c}0.46 \\
(0.51-0.53)\end{array}$ & $\begin{array}{c}0.61 \\
(0.68-0.69)\end{array}$ & \\
\hline 1 & $\begin{array}{c}0.63 \\
\pm 0.04 \mathrm{~b}\end{array}$ & $\begin{array}{c}0.64 \\
\pm 0.02 \mathrm{ab} \mathrm{A}\end{array}$ & $\begin{array}{c}0.64 \\
\pm 0.03 \mathrm{a}\end{array}$ & $\begin{array}{c}0.66 \\
\pm 0.02 \mathrm{abA}\end{array}$ & $\begin{array}{c}0.64 \\
\pm 0.03 \mathrm{abAB}\end{array}$ & $\begin{array}{c}0.65 \\
\pm 0.02 \mathrm{ab}\end{array}$ & $\begin{array}{c}0.64 \\
\pm 0.03 \mathrm{ab}\end{array}$ & $\begin{array}{c}0.64 \\
\pm 0.02 \mathrm{ab}\end{array}$ & $\begin{array}{c}0.65 \\
\pm 0.06 \mathrm{ab}\end{array}$ & $\begin{array}{c}0.64 \\
\pm 0.03 x\end{array}$ \\
\hline 2 & $\begin{array}{c}0.64 \\
\pm 0.04\end{array}$ & $\begin{array}{c}0.64 \\
\pm 0.02 \mathrm{~A}\end{array}$ & $\begin{array}{c}0.64 \\
\pm 0.03\end{array}$ & $\begin{array}{c}0.65 \\
\pm 0.02 \mathrm{~A}\end{array}$ & $\begin{array}{c}0.65 \\
\pm 0.03 \mathrm{~A}\end{array}$ & $\begin{array}{c}0.64 \\
\pm 0.02\end{array}$ & $\begin{array}{c}0.65 \\
\pm 0.02\end{array}$ & $\begin{array}{c}0.64 \\
\pm 0.02\end{array}$ & $\begin{array}{c}0.64 \\
\pm 0.06\end{array}$ & $\begin{array}{c}0.64 \\
\pm 0.03 \mathrm{x}\end{array}$ \\
\hline 3 & $\begin{array}{c}0.64 \\
\pm 0.03\end{array}$ & $\begin{array}{c}0.65 \\
\pm 0.02 \mathrm{~A}\end{array}$ & $\begin{array}{c}0.64 \\
\pm 0.02\end{array}$ & $\begin{array}{c}0.65 \\
\pm 0.03 \mathrm{~A}\end{array}$ & $\begin{array}{c}0.65 \\
\pm 0.03 \mathrm{~A}\end{array}$ & $\begin{array}{c}0.64 \\
\pm 0.02\end{array}$ & $\begin{array}{c}0.65 \\
\pm 0.02\end{array}$ & $\begin{array}{c}0.64 \\
\pm 0.03\end{array}$ & $\begin{array}{c}0.63 \\
\pm 0.09\end{array}$ & $\begin{array}{c}0.64 \\
\pm 0.04 \mathrm{x}\end{array}$ \\
\hline 4 & $\begin{array}{c}0.65 \\
\pm 0.03\end{array}$ & $\begin{array}{c}0.65 \\
\pm 0.02 \mathrm{~A}\end{array}$ & $\begin{array}{c}0.64 \\
\pm 0.02\end{array}$ & $\begin{array}{c}0.65 \\
\pm 0.02 \mathrm{~A}\end{array}$ & $\begin{array}{c}0.64 \\
\pm 0.05 \mathrm{AB}\end{array}$ & $\begin{array}{c}0.64 \\
\pm 0.02\end{array}$ & $\begin{array}{c}0.64 \\
\pm 0.03\end{array}$ & $\begin{array}{c}0.63 \\
\pm 0.06\end{array}$ & $\begin{array}{c}0.64 \\
\pm 0.02\end{array}$ & $\begin{array}{c}0.64 \\
\pm 0.03 \mathrm{x}\end{array}$ \\
\hline 5 & $\begin{array}{c}0.64 \\
\pm 0.02\end{array}$ & $\begin{array}{c}0.65 \\
\pm 0.03 \mathrm{~A}\end{array}$ & $\begin{array}{c}0.64 \\
\pm 0.08\end{array}$ & $\begin{array}{c}0.65 \\
\pm 0.02 \mathrm{~A}\end{array}$ & $\begin{array}{c}0.64 \\
\pm 0.10 \mathrm{AB}\end{array}$ & $\begin{array}{c}0.64 \\
\pm 0.02\end{array}$ & $\begin{array}{c}0.65 \\
\pm 0.02\end{array}$ & $\begin{array}{c}0.65 \\
\pm 0.02\end{array}$ & $\begin{array}{c}0.64 \\
\pm 0.02\end{array}$ & $\begin{array}{c}0.64 \\
\pm 0.05 x\end{array}$ \\
\hline 6 & $\begin{array}{c}0.64 \\
\pm 0.02\end{array}$ & $\begin{array}{c}0.64 \\
\pm 0.04 \mathrm{AB}\end{array}$ & $\begin{array}{c}0.65 \\
\pm 0.03\end{array}$ & $\begin{array}{c}0.64 \\
\pm 0.03 \mathrm{AB}\end{array}$ & $\begin{array}{c}0.64 \\
\pm 0.02 \mathrm{~A}\end{array}$ & $\begin{array}{c}0.64 \\
\pm 0.03\end{array}$ & $\begin{array}{c}0.64 \\
\pm 0.03\end{array}$ & $\begin{array}{c}0.65 \\
\pm 0.02\end{array}$ & $\begin{array}{c}0.64 \\
\pm 0.03\end{array}$ & $\begin{array}{c}0.64 \\
\pm 0.03 \mathrm{x}\end{array}$ \\
\hline 7 & $\begin{array}{c}0.63 \\
\pm 0.10\end{array}$ & $\begin{array}{c}0.64 \\
\pm 0.03 \mathrm{AB}\end{array}$ & $\begin{array}{c}0.62 \\
\pm 0.10\end{array}$ & $\begin{array}{c}0.65 \\
\pm 0.03 \mathrm{AB}\end{array}$ & $\begin{array}{c}0.64 \\
\pm 0.03 \mathrm{AB}\end{array}$ & $\begin{array}{c}0.65 \\
\pm 0.03\end{array}$ & $\begin{array}{c}0.64 \\
\pm 0.03\end{array}$ & $\begin{array}{c}0.63 \\
\pm 0.03\end{array}$ & $\begin{array}{c}0.64 \\
\pm 0.04\end{array}$ & $\begin{array}{c}0.64 \\
\pm 0.05 \mathrm{xy}\end{array}$ \\
\hline 8 & $\begin{array}{c}0.65 \\
\pm 0.02\end{array}$ & $\begin{array}{c}0.65 \\
\pm 0.02 \mathrm{~A}\end{array}$ & $\begin{array}{c}0.64 \\
\pm 0.03\end{array}$ & $\begin{array}{c}0.65 \\
\pm 0.03 \mathrm{AB}\end{array}$ & $\begin{array}{c}0.64 \\
\pm 0.03 \mathrm{AB}\end{array}$ & $\begin{array}{c}0.64 \\
\pm 0.02\end{array}$ & $\begin{array}{c}0.64 \\
\pm 0.03\end{array}$ & $\begin{array}{c}0.64 \\
\pm 0.03\end{array}$ & $\begin{array}{c}0.64 \\
\pm 0.03\end{array}$ & $\begin{array}{c}0.64 \\
\pm 0.03 \mathrm{x}\end{array}$ \\
\hline 9 & $\begin{array}{c}0.63 \\
\pm 0.02\end{array}$ & $\begin{array}{c}0.62 \\
\pm 0.03 \mathrm{~B}\end{array}$ & $\begin{array}{c}0.62 \\
\pm 0.10\end{array}$ & $\begin{array}{c}0.64 \\
\pm 0.03 \mathrm{AB}\end{array}$ & $\begin{array}{c}0.63 \\
\pm 0.06 \mathrm{AB}\end{array}$ & $\begin{array}{c}0.63 \\
\pm 0.06\end{array}$ & $\begin{array}{c}0.64 \\
\pm 0.03\end{array}$ & $\begin{array}{c}0.63 \\
\pm 0.02\end{array}$ & $\begin{array}{c}0.63 \\
\pm 0.03\end{array}$ & $\begin{array}{c}0.63 \\
\pm 0.05 \mathrm{y}\end{array}$ \\
\hline 10 & $\begin{array}{c}0.63 \\
\pm 0.03 \mathrm{ab}\end{array}$ & $\begin{array}{c}0.64 \\
\pm 0.03 \mathrm{aAB}\end{array}$ & $\begin{array}{c}0.63 \\
\pm 0.03 \mathrm{ab}\end{array}$ & $\begin{array}{c}0.63 \\
\pm 0.03 \mathrm{abB}\end{array}$ & $\begin{array}{c}0.61 \\
\pm 0.10 \mathrm{bB}\end{array}$ & $\begin{array}{c}0.64 \\
\pm 0.03 \mathrm{ab}\end{array}$ & $\begin{array}{c}0.64 \\
\pm 0.03 \mathrm{a}\end{array}$ & $\begin{array}{c}0.64 \\
\pm 0.04 \mathrm{ab}\end{array}$ & $\begin{array}{c}0.63 \\
\pm 0.03 \mathrm{ab}\end{array}$ & $\begin{array}{c}0.63 \\
\pm 0.04 \mathrm{y}\end{array}$ \\
\hline $\begin{array}{l}\text { Overall } \\
\text { dripline }\end{array}$ & $\begin{array}{c}0.64 \\
\pm 0.04 \mathrm{~b}\end{array}$ & $\begin{array}{c}0.64 \\
\pm 0.03 \mathrm{ab}\end{array}$ & $\begin{array}{c}0.63 \\
\pm 0.05 \mathrm{~b}\end{array}$ & $\begin{array}{r}0.65 \\
\pm 0.03 \mathrm{a}\end{array}$ & $\begin{array}{c}0.63 \\
\pm 0.06 \mathrm{~b}\end{array}$ & $\begin{array}{c}0.64 \\
\pm 0.03 \mathrm{ab}\end{array}$ & $\begin{array}{c}0.64 \\
\pm 0.03 \mathrm{ab}\end{array}$ & $\begin{array}{c}0.64 \\
\pm 0.03 \mathrm{~b}\end{array}$ & $\begin{array}{c}0.64 \\
\pm 0.05 \mathrm{~b}\end{array}$ & -- \\
\hline
\end{tabular}

[a] Within each section and overall dripline, different lowercase letters (a and b) show significant differences among flushing treatments ( $\mathrm{p}<0.05)$.

Within each flushing treatment, different uppercase letters (A and B) show significant differences among dripline sections ( $<<0.05$ ).

[b] Within all flushing treatments, different letters ( $\mathrm{x}$ and $\mathrm{y})$ show significant differences among dripline sections $(\mathrm{p}<0.05)$.

\section{CONCLUSiOnS}

Flushing of driplines continues to be an important aspect in maintaining good performance and ensuring longevity of SDI systems. Sediment deposition, sediment removal during flushing, and emitter discharge reduction was examined for an SDI system having an average field slope of $0.31 \%$ and with water pumped from a reservoir with an average TSS of approximately $19 \mathrm{mg} / \mathrm{L}$ for 30 days (total irrigation period of $371 \mathrm{~h}$ ). The water quality in this experiment was in the midrange of a series of microirrigation studies using biological effluent summarized by Trooien and Hills (2007). The field slope is in the midrange of many SDI systems in the U.S. Great Plains and should have had only minimal effect on the results of this study since the velocity head during flushing is a much larger factor than elevation head for most SDI systems. Sediment deposition within the SDI dripline was significantly greater when no flushing was performed during the course of the experiment and was nearly 3 times greater than for those driplines that were flushed. Sediment deposition within the nonflushed dripline was actually greatest nearer the inlet, reaching a maximum at about $1 / 3$ of the distance along the dripline, which suggests settling of particles in laminar flow within the dripline and also possibly increased adhesion and conglomeration as additional sediments passed through these inlet sections. There were significantly greater total sediments in the flushwater from the driplines that had a single flushing and a flushing velocity of approximately $0.68 \mathrm{~m} / \mathrm{s}$, as compared to the smallest flushing velocity (approximately $0.35 \mathrm{~m} / \mathrm{s}$ ) treatments, which indicates that greater flushing velocities remove more solids from the drip- lines, as would be anticipated. The effect of flushing velocity versus flushing volume cannot be separated in this study because of the fixed $15 \mathrm{~min}$ duration of flushing. The pattern of sediment deposition within the flushed driplines was different from that of the non-flushed driplines. There was sometimes greater deposition near the inlets for the flushed driplines, particularly with smaller flushing velocities, and greater solids deposition closer to the distal ends when flushing velocity was greater. These differences suggest that the flushing events were not of sufficient duration to remove the sediments completely from the dripline. The sediment deposition and movement appear to follow known theory about deposits moving in a sand dune fashion within a pipe (Shannon et al., 1982; Abulnaga, 2002). We also observed this sand dune-type movement anecdotally with sand particles in clear tubes in laboratory tests that were not part of this study.

There was an inconsistent effect of flushing frequency on sediment removal from the dripline as measured in the flushing water and on the amount and location of sediments remaining in the driplines. There was numerically greater sediment removal for a single flushing at the greatest flushing velocity, but as flushing velocity decreased, there tended to be slightly better sediment removal with more frequent flushing. A greater solids deposition with the less frequent flushing conceivably may have resulted in an increased localized flushing velocity at the point of deposition, causing more erosion of the deposition and thus greater removal by the flushing water. Another possibility may be that increased aggregate size with less frequent flushing had a dragging effect on the deposits, thus carrying more in the flushing water. 
Although not a factor in this study, increasing the duration of flushing may be a more important and less expensive means (i.e., increased flushing events increase labor requirements, and greater flushing velocities can greatly increase SDI system costs through different pumping requirements and reduced zone size, creating a need for more pipes, controls, and connectors) of increasing the overall effectiveness of flushing, given the manner in which sediments move within the dripline during flushing. The effect of flushing duration should be examined more closely in field and laboratory studies and perhaps through computational fluid dynamics (CFD).

The flushing treatment did not have great effects on the resulting SDI emitter discharges measured at the end of the experiment. The average emitter discharge (all flushing treatments and emitter locations within the field) at the conclusion of the study was statistically significantly less, but only $2.5 \%$ less, than the discharge for new and unused driplines. This suggests that improvements in emitter designs and filtration that have occurred over time have reduced, but not eliminated, SDI emitter clogging concerns.

\section{ACKNOWLedgements}

This article is a joint contribution of the University of Girona (Girona, Spain), Kansas State University (Manhattan, Kansas), and South Dakota State University (Brookings, South Dakota). Contribution No. 10-107-J from the Kansas Agricultural Experiment Station.

\section{REFERENCES}

Abulnaga, B. E. 2002. Chapter 4: Heterogeneous flows of settling slurries. In Slurry Systems Handbook. New York, N.Y.: McGraw Hill.

Adin, A., and M. Sacks. 1991. Dripper-clogging factors in wastewater irrigation. J. Irrig. Drain. Eng. 117(6): 813-827.
ASAE Standards. 2003. EP405.1: Design and installation of microirrigation systems. St. Joseph, Mich.: ASAE.

Camp, C. R., F. R. Lamm, R. G. Evans, and C. J. Phene. 2000. Subsurface drip irrigation: Past, present, and future. In Proc. 4th Decennial National Irrigation Symp., 363-372. St. Joseph, Mich.: ASAE.

Clark, G. A., F. R. Lamm, and D. H. Rogers. 2005. Sensitivity of thin-walled drip tape emitter discharge to water temperature. Applied Eng. in Agric. 21(5): 855-863.

Hills, D. J., and M. J. Brenes. 2001. Microirrigation of wastewater effluent using drip tape. Applied Eng. in Agric. 17(3): 303-308.

Hills, D. J., M. A. Tajrishy, and G. Tchobanoglous. 2000. The influence of filtration on ultraviolet disinfection of secondary effluent for microirrigation. Trans. ASAE 43(6): 1499-1505.

Lamm, F. R., and C. R. Camp. 2007. Chapter 13: Subsurface drip irrigation. In Microirrigation for Crop Production: Design, Operation, and Management, 473-551. Amsterdam, The Netherlands: Elsevier.

Nakayama, F. S., B. J. Boman, and D. J. Pitts. 2007. Chapter 11: Maintenance. In Microirrigation for Crop Production: Design, Operation, and Management, 389-430. Amsterdam, The Netherlands: Elsevier.

Ravina, I., E. Paz, Z. Sofer, A. Marcu, A. Shisha, and G. Sagi. 1992. Control of emitter clogging in drip irrigation with reclaimed wastewater. Irrigation Sci. 13(3): 129-139.

Ravina, I., E. Paz, Z. Sofer, A. Marcu, A. Shisha, G. Sagi, Z. Yechialy, and Y. Lev. 1997. Control of clogging in drip irrigation with stored treated municipal sewage effluent. Agric. Water Mgmt. 33(2-3): 127-137.

Shannon, W. M., L. G. James, D. L. Basset, and W. C. Mih. 1982. Sediment transport and deposition in trickle irrigation laterals. Trans. ASAE 25(1): 160-164.

Tajrishy, M. A., D. J. Hills, and G. Tchobanoglous. 1994. Pretreatment of secondary effluent for drip irrigation. J. Irrig. Drain. Eng. 120(4): 716-731.

Trooien, T. P., and D. J. Hills. 2007. Chapter 9: Application of biological effluent. In Microirrigation for Crop Production: Design, Operation, and Management, 329-356. Amsterdam, The Netherlands: Elsevier. 
